\title{
The Analysis of Standard Agreement in Credit Transactions Through Financial Technology Viewed from Law No. 8 of 1999 Concerning Consumer Protection
}

\author{
Dwi Edi Wibowo, Handriyanto Wijaya, Liana Endah Susanti and Ratna Anggraini \\ Universitas Pekalongan, Indonesia \\ Universitas Sebelas Maret Surakarta, Indonesia \\ E-mail: unikaljaya2018@gmail.com
}

How to cite : Dwi Edi Wibowo. et al. (2019). The Analysis of Standard Agreement in Credit Transactions Through Financial Technology Viewed from Law No.8 of 1999 Concerning Consumer Protection. UNIFIKASI : Jurnal Ilmu Hukum, 6(1), 61-70. DOI : 10.25134/unifikasi.v6i1.1603

Submitted : 04-01-2019 Revised : 31-05-2019 Accepted : 10-06-2019

\begin{abstract}
The rapid development of technology including its use in financial sector has made the process of financial inclusion and literacy easier, especially for a country where its community does not have a high financial understanding. Unfortunately, the practice of Financial Technology (Fintech) which should have put forward Law No. 8 of 1999 concerning Consumer Protection is considered unfavorable for the community. Hence, this study intends to investigate several issues regarding financial technology (fintech) which include the implementation of standard agreement in credit transactions through fintech, the barriers that often occur in credit transactions through fintech, and the settlement of consumer protection disputes related to credit transactions through fintech. This study applied a normative juridical method with a mixed approach, namely statute approach and conceptual approach. The results revealed that standard agreements made unilaterally by creditors often contain standard clauses leading to customers' losses. In one hand, a weak regulation causes fintech users to get less legal umbrella. On the other hand, the creditors are legally innocent because they get the customers' agreement in the standard agreement. Therefore, it can be concluded that there is a need to strengthen regulations relating to consumer service and protection against fintech transactions which include technology, operational security, human resources, and risk management.
\end{abstract}

Keywords: Financial Technology; Standard Agreement; Consumer protection

\section{Analisis terhadap Perjanjian Baku dalam Transaksi Kredit melalui Financial Technology Ditinjau dari Undang-Undang Nomor 8 Tahun 1999 tentang Perlindungan Konsumen}

\begin{abstract}
Abstrak : Tujuan dari penelitian ini yaitu menjawab beberapa persoalan mengenai bagaimanakah pelaksanaan perjanjian baku dalam transaksi kredit melaui fintech, hambatan apa yang kerap terjadi dalam transaksi kredit melalu fintech dan bagaimanakah penyelesaian sengketa perlindungan konsumen terkait transaksi kredit melalui fintech. Metode penelitian yang digunakan adalah yuridis normatif dan pendekatan campuran antara statute approach dan conceptual approach dianggap selaras dengan tujuan dari kajian ini yaitu menjawab beberapa persoalan mengenai bagaimanakah pelaksanaan perjanjian baku dalam transaksi kredit melaui fintech, hambatan apa yang kerap terjadi dalam transaksi kredit melalu fintech dan bagaimanakah penyelesaian sengketa perlindungan konsumen terkait transaksi kredit melalui fintech. Hasil dari penelitian ini Teknologi semakin berkembang dari tahun ke tahun, termasuk pemanfaatanya di bidang finansial. Hal ini membuat proses inklusi dan literasi finansial menjadi lebih mudah, terutama untuk suatu negara yang belum tinggi pemahaman masyarakatnya terhadap finansial. Sayangnya Financial Technology (fintech) yang semestinya mengedepankan Undang-Undang No.8 Tahun 1999 tentang Perlindungan Konsumen belakangan ini justru dianggap sebaliknya. Perjanjian baku yang dibuat secara sepihak oleh kreditur kerap mengandung klausula-klausula baku yang mengarah pada kerugian yang menanti nasabah, terlebih dengan iming-iming instan yang disajikan penyedia jasa kredit melalui fintech dengan mengedepankan slogan cepat dan mudah. Regulasi yang belum matang menyebabkan pengguna fintech kurang mendapat payung hukum, disisi lain pihak kreditur secara hukum tidak bersalah karena mendapat persetujuan nasabah dari perjanjian baku. Simpulan penelitian perlu adanya penguatan regulasi yang berkaitan dengan pelayanan dan perlindungan konsumen terhadap transaksi fintech mencakup pada teknologi, keamanan operasional, sumber daya manusia, serta pengelolaan dan manajemen resiko.
\end{abstract}

Kata Kunci: Financial Technology; Perjanjian Baku; Perlindungan Konsumen 


\section{INTRODUCTION}

Indonesia as an archipelago country faces various problems due to its geographical condition. One of the problems faced in economic field is the issue of financial inclusion. Hence, a condition where all working-age people is able to get effective access to credit, savings, and payment systems needs to be immediately realized and developed in order to overcome poverty and reduce the gap in economic capacity of the community. Financial institutions are part of financial system in modern economy providing financial services for public users. ${ }^{1}$ Based on Presidential Regulation of the Republic of Indonesia No. 82 of 2016 concerning National Strategy for Financial Inclusion (SKNI), the objective of financial inclusion is to increase national economy and reduce the gap in economic capacity of the community.

The attachment of one nation to another is a result of the rapid development of information technology and the stronger attachment of human to thoughts and actions as reflected in the saying, "think globally, act locally". ${ }^{2}$ Along with the development of information technology, the implementation of science and technology is one of the enablers encouraging the expansion of access and use of financial products. In the Elucidation of SKNI Pillars and Foundation, it is declared that infrastructure and information technology is one of the foundations that can support the five Pillars of SKNI. One of the pillars of SKNI is consumer protection. Legal protection for consumers in electronic transactions in Indonesia is strictly regulated both in terms of criminal and civil law. Thus, it is necessary to protect consumers in any financial transactions ${ }^{3}$.

Globalization will affect various aspects in human life, including finance and capital ownership, market strategies in a business competition, technology and knowledge, lifestyle and consumption patterns of the community, legal regulations, political behavior in the world as well as perception and agreement within the community itself. In the current open economic system, especially banking services and other financial services institutions, its business ownership is allowed to be owned by foreign investors. ${ }^{4}$ The rise of financial activities today is an impact of the changes of community behavior pattern in facing globalization. In the era of globalization, people tend to choose instant things. This behavior is one of the factors leading to the formation of Financial Technology (Fintech) in order to support human life. Fintech reflects the development of technology in financial services. Nowadays, financial services by utilizing technology and information (Fintech) is increasingly growing. Hence, there are various registered financial institutions, such as start-up companies, offer financial services through fintech.

Fintech Companies have a wide opportunity due to the determination of Indonesia as the largest market in Southeast Asia in 2025. Up to August 2018, there are 64 Fintech companies registered and licensed by OJK. ${ }^{5}$ The development of Fintech companies in Indonesia is in line with the increasing number of internet and smartphone users. The number of internet users in 2017 reached 143.26 million people or equivalent to $54.68 \%$ of the total population of Indonesia. This number shows an increase of 10.56 million people from 2016 survey. ${ }^{6}$ Besides, $50.08 \%$ of the total population of Indonesia claimed

\footnotetext{
${ }_{1}^{1}$ Sunaryo, 2014, Hukum Lembaga Pembiayaan, Jakarta, Sinar Grafika, p.9.

2 Jawahir Thontowi \& Pranoto Iskandar, 2016, Hukum Internasional Kontemporer, Bandung, PT Refika Aditama, p.21.

${ }^{3}$ Suwari Akhmaddhian \& Asri Agustiwi, Perlindungan Hukum Terhadap Konsumen Dalam Transaksi Jual Beli Secara Elektronik Di Indonesia, Jurnal Unifikasi, ISSN 2354-5976 Vol. 3 No. 2 Juli 2016.40-60.

${ }^{4}$ Sarip \& Diana Fitriana, Legal Antropology on the Application of Village Website in Digital Economic Era in Indonesia, Jurnal Ilmu Hukum UNIFIKASI Volume 05 Nomor 02, Juli 2018, p. 103.

${ }^{5}$ https://www.ojk.go.id/id/berita-dan-kegiatan/publikasi/Pages/Penyelenggara-Fintech-Terdaftar-di-OJK-perAgustus-2018.aspx, Retrieved on 10 March 2019.

${ }^{6}$ https://kominfo.go.id/index.php/content/detail/12640/siaran-pers-no-53hmkominfo022018-tentang-jumlahpengguna-internet-2017-meningkat-kominfo-terus-lakukan-percepatan-pembangunan-broadband/0/siaran_pers
} 
to own and use smartphones to access the internet. ${ }^{7}$ Fintech greatly influences internet and smartphone penetration in the world because it provides ease of communication across regions and times, both transactions between business to peer (B to P), Peer to Peer (P to P), and Government to Peer (G to P).

Credit transactions can be carried out based on written or unwritten agreements. The integration between digital economy and credit transaction can be realized through Fintech. Credit transactions through Fintech will no longer require physical meetings between lenders and borrowers. On the contrary, they can only meet through a Fintech application. The advantages of credit transactions through Fintech are the easy conditions as well as the quick process compared to credit transactions in banking institutions.

However, the ease of applying for a loan through Fintech is often used by business actors to obtain maximum profit by imposing a standard credit agreement that is likely to be ignored by debtors, especially in micro segmentation. This standard credit agreement forces the users to take one of two choices, namely agree or disagree with the contents of the agreement. In many cases, the debtor will immediately approve the standard agreement and never read in detail the clauses in the agreement which can make the debtor's position very weak before the law. The inclusion of standard clauses in credit transaction agreement through Fintech can lead to an unbalanced position between business actors and consumers. Thus, Article 18 paragraph 2 of Consumer Protection Act prohibits business actors from including standard clauses which are difficult to see or cannot be read clearly and difficult to understand because many fintech companies usually apply standards clause that are difficult to see or even hidden. A standard agreement is a forced agreement since consumers only have two choices, namely agree or disagree with the standard agreement (take it or leave it), to obtain the goods or services needed.

Although Law No. 8 of 1999 concerning Consumer Protection has stipulated a prohibition for business actors to include standard clauses in every document and/or agreement concerning the transfer of business actor responsibility (Article 18), in reality, there are still standard clauses containing exclusion clause. Hence, a legal protection is needed for parties whose bargaining positions are weak, so as not to fall into the compulsion to accept agreements made by those whose bargaining positions are more dominant. Law has a role to protect people's interests or provide legal protection for them so that it can be interpreted that law functions as a means of social control. ${ }^{8}$ Therefore, consumers need to get legal protection that can provide legal certainty to all their needs and defend their rights if their positions are harmed by business actors ${ }^{9}$ with the existence of a standard agreement in credit transactions through Fintech which is unfavorable for consumers. Thus, the problems discussed in this study are formulated into the following questions; 1) How is the implementation of standard agreement in credit transactions through Fintech?; 2) What are the barriers that often occur in credit transactions through Fintech?; and 3) How is the settlement of consumer protection disputes related to credit transactions through Fintech?

\section{RESEARCH METHODS}

This study applied a normative juridical method with a mixed approach, namely statute approach and conceptual approach. Meanwhile, the data used in this study were secondary data. The collected data were then analyzed and presented qualitatively.

\footnotetext{
${ }^{7}$ https://techno.okezone.com/read/2018/04/04/207/1882130/masyarakat-indonesia-lebih-suka-buka-internet-viasmartphone, Retrieved on 10 March 2019.

${ }^{8}$ Dian Alan Setiawan, The Implication of Pancasila Values on the Renewal Law in Indonesia, Jurnal Ilmu Hukum UNIFIKASI, Volume 05 Nomor 02, Juli 2018, p. 63.

${ }^{9}$ Ahmadi Miru \& Sutarman Yodo, 2004, Hukum Perlidungan Konsumen, Jakarta, PT Raja Grafindo Persada, p 30
} 


\section{RESULTS AND DISCUSSION}

\section{The Implementation of Standard Agreement in Credit Transactions through Financial Technology}

Globalization in economic field as well as free trade has given a profound impact on the field of law, ${ }^{10}$ especially related to the regulation of financial services through Fintech. Changes in people's lifestyles are rapidly developing due to the impact of globalization. These lifestyle changes lead people to always involve in financial transactions. In addition to lifestyle changes, the advancement of information technology (IT) is also changed drastically from the lives of previous eras. This opportunity is then utilized by business actors to innovate and transform in technologybased financial sector where the conventional things are transferred to digital forms.

The development in the field of Digital Banking Services includes Financing, Investment, and Insurance. Some elements of the development of Digital Banking Services that are closest to people's lives are the financing and investment sectors, especially credit applications or credit loans. Nowadays, many businesses try to provide online credit application services by relying on Fintech where consumers do not have to worry anymore about the long disbursement time, the convoluted process, and the emergence of costs outside the transaction, for example transportation costs. Efficiency in terms of time and cost is what is offered by credit providers in digital banking services.

A new thing that arises and needs to be considered in applying for credit online is the standard agreement. In online credit transactions, standard agreement often causes various problems. The term "standard" refers to a clause implying an engagement and obligation that must be fulfilled by consumers or debtor in which the clauses are determined unilaterally by credit service provider as creditor. According to Law No. 8 of 1999 Concerning Consumer Protection, standard clauses refer to every rule or condition prepared and determined unilaterally by a business actor as stated in a document and/or agreement. These clauses are binding and must be fulfilled by consumers. With regard to these standard clauses, consumers often feel disadvantaged because they think the agreement is not based on deliberation or negotiation so that they are forced to accept it.

The credit lending system from Fintech is based on electronic money credit services with a peer to peer lending system through website platform. This credit transaction is done online through the following stages: ${ }^{11}$

a. Prospective borrowers register as borrowers by accessing P2P-lending services or websites. The registration is done by filling in data on an online form involving name, email, cellphone number, account password, ID card number, home address, marital status, occupation, office address (if working at office), account number, and uploading documents in the form of ID cards, savings book, bank account records for the past 6 months and a guarantor's business card.

b. After registering, the borrowers write down the amount of money to be borrowed, the length of loan and the purpose of using the money. The systems will automatically claculate the amount of interest to be paid monthly by the borrowers.

c. Then, the organizing company verifies and analyzes the loan terms.

d. Prospective borrowers who have been verified and passed will be posted on the website so that the lender can assess and provide funds to the loan.

e. The borrowers wait for the lenders to fund the loan proposal.

\footnotetext{
${ }^{10}$ Adi Sulistyono \& Muhammad Rustamaji, 2009. Hukum Ekonomi Sebagai Panglima, Jawa Timur, Masmedia Buana Pustaka, p. 103.

${ }^{11}$ https://faq.amartha.com/hc/en-us . Retrieved on 28 September 2018.
} 
f. In the same vein, prospective lenders also register by accessing a P2P-lending service application or website.

g. The registration is done by filling in data on an online form and uploading the same documents as the borrowers. Yet, lenders are not required to upload documents in the form of a guarantor's business card and bank account records for the past 6 months. Conversely, they are required to fill in the taxpayer identification number on the online form.

h. The P2P-lending organizing company will verify the data.

i. If the data have been verified and passed, the lenders can see, assess and choose the borrowers who will be given a loan. At this stage, an agreement has been reached between the lender and the borrower.

j. The lenders then transfer funds to P2P-lending company account in which its amount is determined by the lenders. Thus, a lender does not have to meet the borrower's loan amount. One borrower can be funded by two or more lenders.

k. After that, the organizing company transfers the funds to the borrower's account if the total fund has been agreed, whether by a lender or more.

1. After the due date, the borrower will return the lenders' funds along with the interest through the organizing company's account.

m. The organizing company will transfer back the lenders' funds along with the interest after deducting commissions and other costs.

In this case, Fintech Company also carries out loan collections. The collection is carried out in accordance with the power granted by lenders to organizing company based on the contract agreements regulated in POJK 77 of $2016 .{ }^{12}$ Therefore, the community is expected to be rational and selective in using Fintech services despite the conveniences and facilities offered. Here, the role of the financial services authority is an absolute thing since consumer's position is often cornered before the law due to the standard clauses on the agreement that are considered unfavorable have been agreed upon by them.

\section{The Barriers in Credit Transactions through Fintech}

It is common knowledge that Fintech is the impact of globalization through the development of information technology. Thus, it is natural when its application faces various barriers, such as:

a. Good IT infrastructure, facilities and infrastructure are only available in big cities so that people in villages and remote areas are less familiar with Fintech.

b. Consumer data collection is less reliable due to single ID program in which there are still many people who do not have ID card and there are also people who have dual ID cards.

c. Less competent human resources because not all Indonesian people are literate in bankingbased technology. Fintech is not something that anyone can access without special knowledge.

d. The difficulty of realizing a balance between business and social side.

e. The difficulty of building public understanding and trust regarding features and services provided by Fintech service providers.

f. A weak regulation causes Fintech users to get less legal umbrella.

g. Ecosystems and government support which is related to the government's slogan about the glorification of creative industries that overrides technological progress as a basis for stability.

h. There is no clear operational mechanism standard for Fintech, especially in credit financing activities in which there are potential operational risks which include fraud, money laundering, etc.

\footnotetext{
${ }^{12}$ https://www.republika.co.id/berita/ekonomi/keuangan/17/10/27/oyh6xq382-ojk-segera-terbitkan-se-kontrakpinjammeminjam-Fintech, Retrieved on 18 February 2019.
} 
Something new is always tempting, but as a wise person it would be better if we also examine the shortcomings and possible bad possibilities that could occur, including:

a. Overlapping rules need to be evaluated to be more effective and efficient.

b. The potential fraud as an impact of a lack understanding of the use and rules applied by service providers needs to be considered.

c. Innovations that are destructive may happen if people are not able to properly respond to technological advances.

d. There is a risk of leakage of information, privacy and important personal data because the system used is vulnerable to being misused by irresponsible people.

e. Access to personal data in the withdrawal of bad loans is often used to terrorize consumers if they do not immediately settle payment arrears.

Service industry offered by business actors in technology-based finance sector needs special treatment considering that its activities are no longer carried out conventionally, but have shifted to digitalization. It means that more intensive handling related to consumer privacy, regulations, and handling of violations cases of consumer protection rights is needed in order to avoid the disappointment of the community that will affect their trust in the law and government regulations.

\section{The Settlement of Consumer Protection Disputes Related to Credit Transactions through Fintech}

Legal Protection for consumers in credit transactions through Fintech must be well implemented. Civil disputes occurring between investors, debtors and organizing company must also be resolved quickly through Alternative Dispute Resolution (APS). In this case, credit transactions through Fintech must be carried out based on Law No. 21 of 2011 concerning Financial Services Authority (OJK), Law No. 11 of 2008 concerning Information and Electronic Transactions (ITE), Law No. 8 of 1999 concerning Consumer Protection, Law No. 7 of 2014 concerning Trade, Law No. 8 of 2010 concerning Money Laundering, Law No. 40 of 2007 concerning Limited Liability Companies, Law No. 25 of 1992 concerning Cooperatives, Law No. 30 of 1999 concerning Arbitration and Alternative Dispute Resolution, Civil Code, and other related regulations. Online business activities and credit transactions through Fintech are related to Law No. 8 of 1999 concerning Consumer Protection. Communities who buy products (goods/services) or conduct credit transactions through Fintech must obtain legal protection so that they are not disadvantaged by business actors. OJK is very concerned about aspects of consumer protection marked by the issuance of OJK Regulation No. 1/POJK.07/2013 concerning Consumer Protection in Financial Services Sector and Circular Letter of Financial Services Authority No. 2/SEOJK.07/2014 concerning Services and Settlement of Consumer Complaints to Financial Service Business Actors. Fraudulent criminal acts occurring in credit transactions through Fintech need to be handled through the application of fraud article in the Criminal Code (KUHP). In handling fraud, consumers can report to the Police, while the settlement of consumer disputes with business actors can be resolved through the Consumer Dispute Settlement Body (BPSK). Basically, the aspects of consumer protection in online business and credit transactions through Fintech are regulated in Article 49 of Government Regulation No. 82 of 2012 concerning the Implementation of Electronic Systems and Transactions stating that business actors must provide clear information regarding contract or advertisement offers and must provide complete and correct information related to the contract terms, manufacturers, and products offered. If a dispute related to credit transactions through fintech occurred, the person or business entity experiencing the dispute can 
resolve it through the court or through other dispute resolution mechanisms, including consultation, negotiation, conciliation, mediation, and arbitration in accordance with the Law. ${ }^{13}$

\section{The Solution to Problems in Credit Transactions through Fintech}

Basically, OJK and BI have issued several regulations related to their authority regarding Fintech, such as:

a. Regulation of Financial Services Authority (POJK) No. 77/POJK.01/2016 concerning Information Technology-Based Money Lending Services (LPMUBTI) regulating various matters that must be obeyed by Fintech peer to peer lending (P2P lending) Companies. Basically, POJK No. 77/POJK.01/2016 aims to protect consumers related to the security of funds and data, prevent money laundering and terrorism financing, and stabilize financial system. This regulation also regulates the limitation of share ownership, minimum capital, maximum loan and interest limits, the necessity of making an escrow account, as well as other principles that must be applied by Fintech companies.

b. Regulation of Bank Indonesia (PBI) No. 18/40/PBI/2016 concerning Implementation of Payment Transaction Processing (PTP) which regulates payment transactions processing, licensing and approvals in organizing payment transaction processing, obligations in carrying out payment transaction processing, reports, licensing transfer of payment system service provider and supervision, prohibitions, and sanctions.

c. Regulation of Bank Indonesia (PBI) No. 19/12/PBI/2017 concerning Implementation of Financial Technology which aims to support the creation of monetary stability, financial system stability, and payment systems that are efficient, safe and reliable to support sustainable and inclusive national economic growth by applying the principles of consumer protection, risk management and prudence.

However, some of these regulations are considered to be lacking in reaching various financial technology sectors that offer various services and bring convenience to the public in conducting transactions. Hence, the following actions need to be carried out:

1) Providing a licensing mechanism established by Fintech service providers in which the safety standards for consumers are determined by the relevant authorized institutions.

2) Strengthening regulations relating to consumer service and protection against Fintech transactions which include technology, operational security, human resources, and risk management.

3) Considering that Fintech is a sector that is systematically related to various financial authorities, Fintech needs close cooperation and coordination with OJK, Bank Indonesia (BI), the Ministry of Communication and Information, the Ministry of Trade, the Ministry of Industry, as well as other regulators.

In addition to organizing bad possibilities by applying these principles, layered treatment must be applied to overcome the problems experienced by consumers. The appropriate procedures that can be applied include the following:

a. Fintech service providers must have a customer service unit where consumers can express their aspirations and complain about bad services in order to resolve disputes.

b. The Indonesian Fintech Association (Aftech) as the second layer in this procedure is an association that helps resolve consumer disputes with service providers.

c. If the two procedures do not help, the Financial Services Authority (OJK) will contribute to resolve disputes. As a follow up action, OJK has established a Fintech Center that functions to build Fintech ecosystem that is beneficial to the community. Here, Fintech Center and

\footnotetext{
${ }^{13}$ Iswi Hariyani, Perlindungan Hukum dan Penyelesaian Sengketa Bisnis Jasa PM-Tekfin, Jurnal Legislasi Indonesia , Kemenhumham., Vol 5 on 25 May 2005, p 34
} 
startup companies can discuss and synergize with Fintech business actors and test their business model through regulatory sandbox. ${ }^{14}$

\section{CONCLUSION}

Based on the Results of the Analysis Above, Conclusions can be Taken as Follows:

1. The implementation of standard agreement in credit transactions through Financial Technology:

a. Prospective borrowers register as borrowers by accessing P2P-lending services or websites. The registration is done by filling in data on an online form involving name, email, cellphone number, account password, ID card number, home address, marital status, occupation, office address (if working at office), account number, and uploading documents in the form of ID cards, savings book, bank account records for the past 6 months and a guarantor's business card.

b. After registering, the borrowers write down the amount of money to be borrowed, the length of loan and the purpose of using the money. The systems will automatically claculate the amount of interest to be paid monthly by the borrowers.

c. The prospective borrowers who have been verified and passed will be posted on the website, so that the lender can assess and provide funds to the loan. The borrowers wait for the lenders to fund the loan proposal. In the same vein, prospective lenders also register by accessing a P2P-lending service application or website. The registration is done by filling in data on an online form and uploading the same documents as the borrowers. Yet, lenders are not required to upload documents in the form of a guarantor's business card and bank account records for the past 6 months. Conversely, they are required to fill in the taxpayer identification number on the online form. The P2P-lending organizing company will verify the data. If the data have been verified and passed, the lenders can see, assess and choose the borrowers who will be given a loan. At this stage, an agreement has been reached between the lender and the borrower. The lenders then transfer funds to P2P-lending company account in which its amount is determined by the lenders.

d. The organizing company transfers the funds to the borrower's account if the total fund has been agreed. After the due date, the borrower will return the lenders' funds along with the interest through the organizing company's account. The organizing company will transfer back the lenders' funds along with the interest after deducting commissions and other costs.

2. The barriers in credit transactions through Fintech

a. Good IT infrastructure, facilities and infrastructure, consumer data collection is less reliable due to single ID program, and not all Indonesian people are literate in banking-based technology.

b. The difficulty of realizing a balance between business and social side as well as the difficulty of building public understanding and trust regarding features and services provided by Fintech service providers.

c. A weak regulation causes Fintech users to get less legal umbrella, ecosystems and government support, and there is no clear operational mechanism standard for Fintech.

3. The settlement of consumer protection disputes related to credit transactions through Fintech, Consumer protection in online business and credit transactions through Fintech are regulated in Article 49 of Government Regulation No. 82 of 2012 concerning the Implementation of Electronic Systems and Transactions stating that business actors must provide clear information regarding contract or advertisement offers and must provide complete and correct information related to the

\footnotetext{
${ }^{14}$ https://katadata.co.id/berita/2018/08/15/lindungi-konsumen-ojk-siapkan-aturan-inovasi-keuangan-digital, Retrieved on 12 March 2019.
} 
contract terms, manufacturers, and products offered. If a dispute related to credit transactions through fintech occurred, the person or business entity experiencing the dispute can resolve it through the court or through other dispute resolution mechanisms, including consultation, negotiation, conciliation, mediation, and arbitration in accordance with the Law.

\section{SUGGESTION}

1. In terms of the implementation of standard agreement in credit transactions through Financial Technology, it is necessary to have legislations governing the creation of standard clauses that regulate the rights and obligations of business actors/creditors and consumers/debtors in conducting standard agreements and implementing the standard agreements in credit transactions through fintech.

2. In terms of barriers that often occur in credit transactions through fintech, close cooperation and coordination between financial authorities need to be established to provide solutions against the problems since the regulations issued by OJK and BI are considered to be unable to overcome these problems. The actions that can be done are creating a special standardized licensing mechanism, strengthening and reinforcing regulations, and strengthening coordination and cooperation between related sectors. Besides, the active role of the community in anticipating these risks is also important.

3. In terms of settlement of consumer protection disputes related to credit transactions through Fintech, close cooperation and coordination between financial authorities need to be established to provide solutions against the problems since the regulations issued by OJK and $\mathrm{BI}$ are considered to be unable to overcome these problems. The actions that can be done are creating a special standardized licensing mechanism, strengthening and reinforcing regulations, and strengthening coordination and cooperation between related sectors. Besides, the active role of the community in anticipating these risks is also important. There is a need to have legislations governing the creation of standard clauses that regulate the rights and obligations of business actors/creditors and consumers/debtors in in conducting standard agreements which aim to obtain legal certainty and balance for both parties. This is due to the fact that, in practice, standard clauses are often made unilaterally by business actors/creditor resulting in consumers/debtors who are not participating in making standard clauses claim to feel cheated, even though both parties have agreed to sign the agreement. Hence, this results in a condition where parties who should have be sanctioned cannot be sanctioned because the existing legislation only regulates consumer protection.

\section{REFERENCES}

\section{Books and Journals}

Adi Sulistyono and Muhammad Rustamaji, 2009. Hukum Ekonomi Sebagai Panglima, Surabaya : Masmedia Buana Pustaka

Ahmadi Miru and Sutarman Yodo, 2004. Hukum Perlidungan Konsumen, Jakarta, PT Raja Grafindo Persada

Dian Alan Setiawan. 2018. "The Implication of Pancasila Values on the Renewal Law in Indonesia", UNIFIKAS : Jurnal Ilmu Hukum, Volume 05 Nomor 02, Juli 2018.

Iswi Hariyani. 2005. "Perlindungan Hukum dan Penyelesaian Sengketa Bisnis Jasa PM-Tekfin", Jurnal Legislasi Indonesia, Kemenhumham., Vol 5 tanggal 25 Mei 2005.

Jawahir Thontowi and Pranoto Iskandar, 2016, Hukum Internasional Kontemporer, Bandung, PT Refika Aditama.

Sarip and Diana Fitriana. 2018. "Legal Antropology on the Application of Village Website in Digital Economic Era in Indonesia", UNIFIKASI : Jurnal Ilmu Hukum Volume 05 Nomor 02, Juli 2018.

Sunaryo, 2014, Hukum Lembaga Pembiayaan, Jakarta, Sinar Grafika. 
Suwari Akhmaddhian and Asri Agustiwi. 2016. "Perlindungan Hukum Terhadap Konsumen Dalam Transaksi Jual Beli Secara Elektronik Di Indonesia", UNIFIKASI : Jurnal Ilmu Hukum, ISSN 2354-5976 Vol. 3 No. 2 Juli 2016.40-60.

\section{Websites}

https://www.ojk.go.id/id/berita-dan-kegiatan/publikasi/Pages/Penyelenggara-Fintech-Terdaftar-di-OJKper-Agustus-2018.aspx, Retrieved on 10 March 2019.

https://kominfo.go.id/index.php/content/detail/12640/siaran-pers-no-53hmkominfo022018-tentangjumlah-pengguna-internet-2017-meningkat-kominfo-terus-lakukan-percepatan-pembangunanbroadband/0/siaran_pers

https://techno.okezone.com/read/2018/04/04/207/1882130/masyarakat-indonesia-lebih-suka-bukainternet-via-smartphone, Retrieved on 10 March 2019.

https://faq.amartha.com/hc/en-us . Retrieved on 28 September 2018. https://www.republika.co.id/berita/ekonomi/keuangan/17/10/27/oyh6xq382-ojk-segera-terbitkan-sekontrak-pinjammeminjam-Fintech, Retrieved on 18 February 2019.

https://katadata.co.id/berita/2018/08/15/lindungi-konsumen-ojk-siapkan-aturan-inovasi-keuangandigital, Retrieved on 12 March 2019. 